\title{
Histologic Examination of a Sea Pig (Scotoplanes sp.) Using Bright Field Light Microscopy
}

\author{
Elise E. B. LaDouceur ${ }^{1, *(1)}$, Linda A. Kuhnz ${ }^{2}$, Christina Biggs ${ }^{3}$, Alicia Bitondo ${ }^{3}$, Megan Olhasso ${ }^{3}$, \\ Katherine L. Scott ${ }^{1}$ and Michael Murray ${ }^{3}$ \\ 1 Joint Pathology Center, 606 Stephen Sitter Ave, Silver Spring, MD 20910, USA; \\ Katherine.1.scott12.mil@mail.mil \\ 2 Monterey Bay Aquarium Research Institute, 7700 Sandholdt Rd, Moss Landing, CA 95039, USA; \\ lkuhnz@mbari.org \\ 3 Monterey Bay Aquarium, 886 Cannery Roy, Monterey, CA 93940, USA; CBiggs@mbayaq.org (C.B.); \\ ABitondo@mbayaq.org (A.B.); MOlhasso@mbayaq.org (M.O.); mmurray@mbayaq.org (M.M.) \\ * Correspondence: elise.e.ladouceur.civ@mail.mil; Tel.: +1-301-295-6196
}

Citation: LaDouceur, E.E.B.; Kuhnz, L.A.; Biggs, C.; Bitondo, A.; Olhasso, M.; Scott, K.L.; Murray, M. Histologic Examination of a Sea Pig (Scotoplanes sp.) Using Bright Field Light Microscopy. J. Mar. Sci. Eng. 2021, 9, 848. https://doi.org/10.3390/ jmse 9080848

Academic Editor: Azizur Rahman

Received: 22 June 2021

Accepted: 5 August 2021

Published: 6 August 2021

Publisher's Note: MDPI stays neutral with regard to jurisdictional claims in published maps and institutional affiliations.

Copyright: (c) 2021 by the authors. Licensee MDPI, Basel, Switzerland. This article is an open access article distributed under the terms and conditions of the Creative Commons Attribution (CC BY) license (https:// creativecommons.org/licenses/by/ $4.0 /)$

\begin{abstract}
Sea pigs (Scotoplanes spp.) are deep-sea dwelling sea cucumbers of the phylum Echinodermata, class Holothuroidea, and order Elasipodida. Few reports are available on the microscopic anatomy of these deep-sea animals. This study describes the histologic findings of two, wild, male and female Scotoplanes sp. collected from Monterey Bay, California. Microscopic findings were similar to other holothuroids, with a few notable exceptions. Sea pigs were bilaterally symmetrical with six pairs of greatly enlarged tube feet arising from the lateral body wall and oriented ventrally for walking. Neither a rete mirabile nor respiratory tree was identified, and the large tube feet may function in respiration. Dorsal papillae protrude from the bivium and are histologically similar to tube feet with a large, muscular water vascular canal in the center. There were 10 buccal tentacles, the epidermis of which was highly folded. Only a single gonad was present in each animal; both male and female had histologic evidence of active gametogenesis. In the male, a presumed protozoal cyst was identified in the aboral intestinal mucosa, and was histologically similar to previous reports of coccidians. This work provides control histology for future investigations of sea pigs and related animals using bright field microscopy.
\end{abstract}

Keywords: holothuroidea; deep sea; elasipodida; anatomy; morphology; sea cucumbers

\section{Introduction}

Sea pigs (Scotoplanes spp.) are animals of the phylum Echinodermata, class Holothuroidea, and order Elasipodida. Echinoderms include five extant classes: Crinoidea, Asteroidea, Ophiuroidea, Echinoidea, and Holothuroidea. Echinoderms may have pseudoradial or bilateral symmetry, the latter of which is more common in holothuroids [1]. All echinoderms have a unique type of connective tissue called mutable collagenous tissue that allows them to relax and stiffen their dermis at will. Mutable collagenous tissue is necessary for evisceration and autotomy, which allows echinoderms to voluntarily expel internal viscera and release arms, respectively. Holothuroids are sea cucumbers that collectively occupy a large number of ecological niches. Approximately $1 / 3$ of all holothuroids live in the deep sea [2].

The order Elasipodida includes holothuroids that are deep-sea dwelling [3]. The ocean covers approximately $71 \%$ of earth's surface, with about $90 \%$ of it considered deep sea (>200 m depth) [4]. The deep sea is a harsh environment with extremes in temperature, pressure, resources, and darkness [5]. Deep-sea dwellers are uncommonly examined due to the difficulty in obtaining specimens [6].

The individual specimens investigated here (Scotoplanes sp.) are likely representative of an undescribed species [7]. Their thus-far established depth range is from 985-1900 m, 
and they have been directly observed as sediment ingesters [8]. The hypothesis is that this previously unexamined, deep-sea dwelling Scotoplanes sp. is histologically similar to shallow-water holothuroids, which have been studied in histological detail [9-20].

\section{Materials and Methods}

Two sea pigs (Scotoplanes sp.), one male (10.8 cm total dead specimen length) and one female $(8.9 \mathrm{~cm}$ total dead specimen length), were collected via suction sampler from the sediment-laden seafloor at $1050 \mathrm{~m}$ depth on Smooth Ridge, Monterey Bay, CA, USA $\left(36^{\circ} 50.184^{\prime} \mathrm{N}\right.$ lat, $122^{\circ} 09^{\prime} \mathrm{W}$ long.) using the Monterey Bay Aquarium Research Institute's $R / V$ Rachel Carson and remotely operated vehicle Ventana. After collection, the animals collapsed and were nonresponsive as assessed by lack of body turgor and lack of any response to digital manipulation. Additional chemical sedation was not pursued as the animals were already nonresponsive, and euthanasia was accomplished through $48 \mathrm{~h}$ immersion in $10 \%$ neutral buffered formalin. After complete fixation, transverse, coronal sections were made of the body at $1 \mathrm{~cm}$ intervals and processed for histology. After initial sectioning, the dorsal papillae (also known as antennae; [20]), eviscerated digestive tract, gonads, and buccal tentacles were cut away from the body; additional transverse and longitudinal sections were made of these organs and processed for histology. All tissue sections were processed routinely for histology using a Tissue-Tek VIP 6 AI vacuum infiltration processor (Sakura Finetek, Torrance, CA, USA) using the overnight protocol. Tissues were embedded in paraffin, sectioned in $5 \mu \mathrm{m}$-thick sections, and stained with hematoxylin and eosin. Decalcification was not performed as there were no grossly gritty or hard tissues. Histology slides were scanned using an Aperio GT450 slide scanner (Leica Biosystems, Buffalo Grove, IL, USA), and viewed and photographed using Aperio ImageScope software (Leica Biosystems, Buffalo Grove, IL, USA).

\section{Results}

On gross examination, the body was bilaterally symmetrical with six pairs of large tube feet (12 feet total) extending from the trivium (i.e., ventrum) and oriented ventrally. The tube feet are the largest at mid-body and smallest near the anus. Ten specialized buccal tentacles (also called circumoral tentacles) circumferentially surround the oral cavity [21]. Two pairs of dorsal papillae are on the bivium (i.e., dorsum; Figure 1).

Histologically, the body wall consists of an epidermis and coelomic epithelium separated by the dermis. A thin cuticle covers the simple epidermis, which is composed of columnar epithelium. The body wall is variably convoluted with numerous infoldings, particularly around the buccal tentacles (Figure 2). The dermis is composed of mutable collagenous tissue and encloses canals and nerves, most of which run longitudinally along the length of the body wall. There are occasional crystalline, mineralized deposits in the dermis known as ossicles or sclerites, especially around the buccal tentacles, that polarize and frequently fall out of histologic section (artifact). The center of the animal has a large, fluid-filled coelom (also called perivisceral coelom) lined by a single layer of cuboidal to flattened coelomic epithelium.

External appendages include the tube feet, dorsal papillae, and buccal tentacles, all of which have the same histologic layers (i.e., epidermis, dermis, and myoepithelium lining a central water vascular canal). The epidermis around the tube feet contains larger numbers of secretory cells than the other appendages and is supported by subepidermal glands. Tube feet have thick longitudinal retractor muscles. Dorsal papillae and buccal tentacles are lined externally by a highly folded epidermis with an external cuticle and have a central water vascular channel similar to those seen in tube feet. 


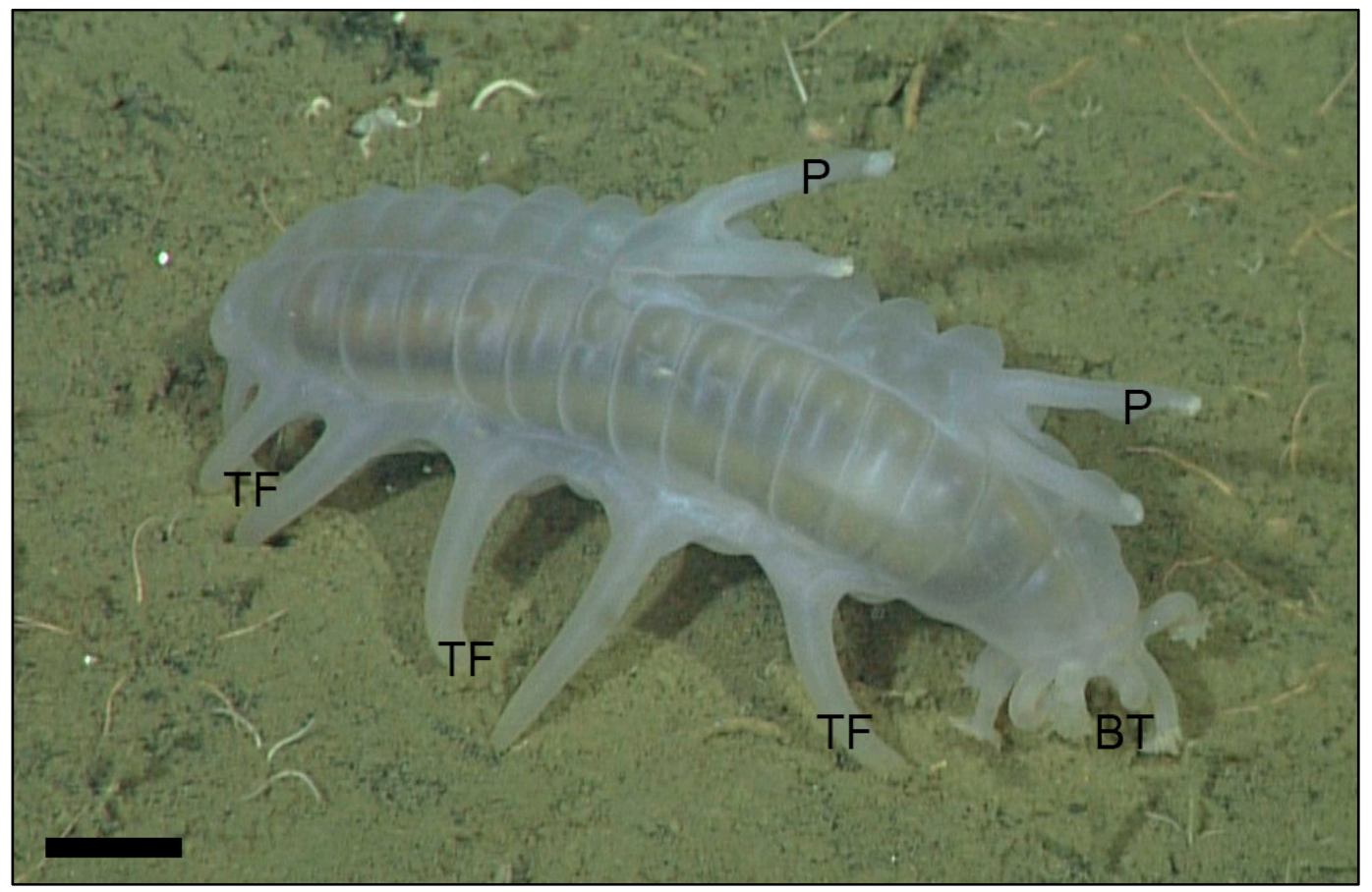

Figure 1. In situ image of Scotoplanes sp., taken from the remotely operated vehicle Doc Ricketts using an Ikegama highdefinition camera fitted with a HA10Xt.2 Fujinon lens. The mouth is surrounded by 10 modified tube feet, called buccal tentacles (BT), which are used for feeding. Six pairs of tube feet (TF) line the lateral body wall and are oriented ventrally for walking. Two sets of paired elongate papillae (P) extend from the dorsal body wall (i.e., bivium). Total body length $=14 \mathrm{~cm}$. Scale bar $=2 \mathrm{~cm}$. MBARI 2014, $1438 \mathrm{~m}$ depth, Monterey Bay, CA, USA.
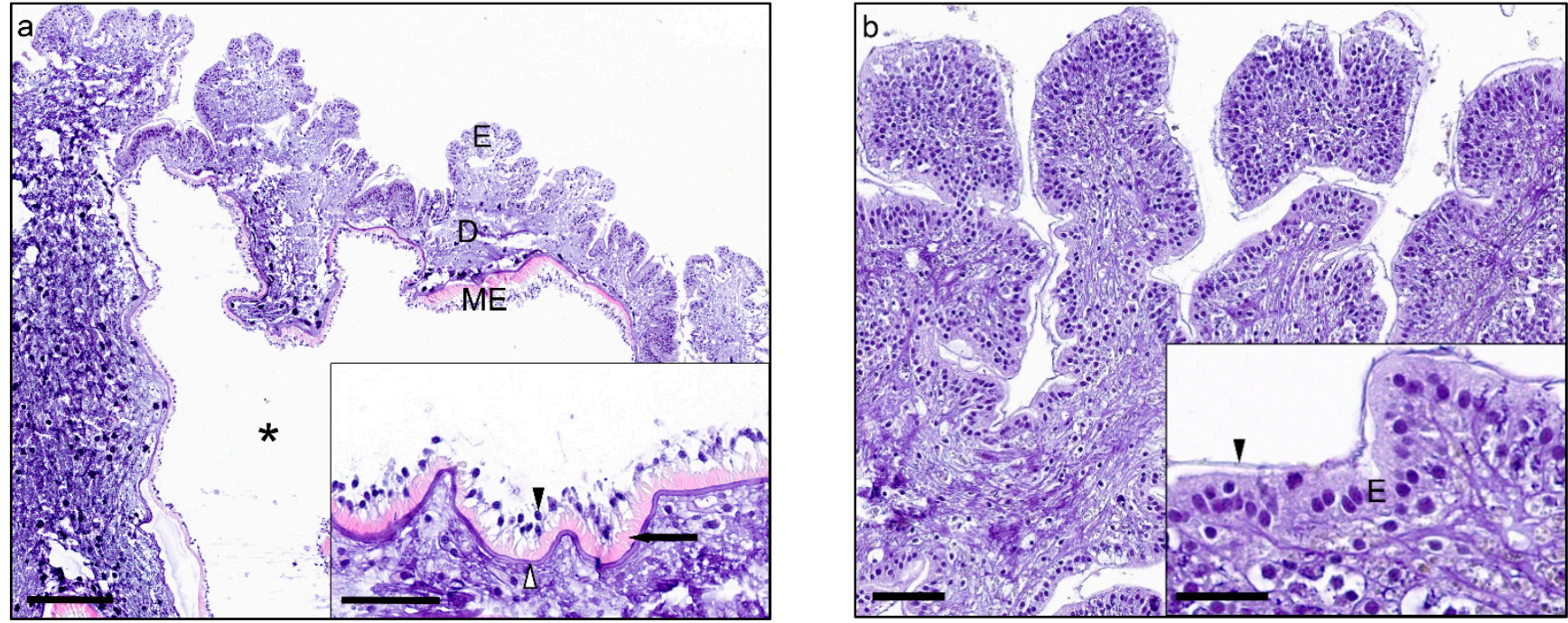

Figure 2. Histologic sections of the buccal tentacles of a sea pig (Scotoplanes sp.) stained with hematoxylin and eosin. (a) Asterisk, water vascular canal; D, dermis; E, epidermis; ME, myoepithelium. Scale bar $=200 \mu \mathrm{m}$. Inset: The myoepothelium has oval, apical nuclei (black arrowhead) subtended by muscle fibers (arrow) aligned on a thick basement membrane (white arrowhead). Scale bar $=60 \mu \mathrm{m}$. (b) The epidermis is highly folded and arranged into arborizing papillary projections. Scale bar $=60 \mu \mathrm{m}$. Inset: Arrowhead, cuticle; E, epidermis. Scale bar $=30 \mu \mathrm{m}$.

The alimentary canal in both animals was eviscerated prior to examination (likely due to stress of capture). Aside from the buccal tentacles and anus, the alimentary canal has a thin wall composed of a small amount of collagenous stroma with an external coelomic epithelial lining and an internal digestive mucosa. The digestive mucosa is composed of tall columnar epithelium with digestive granules oriented apically towards the lumen. 
Surrounding the buccal tentacles, the anterior alimentary canal is lined internally by a cuticle and is bounded externally by muscle. Additionally, the oral mucosa is highly folded with increased numbers of digestive granules compared to aboral sections (Figure 3). In the aboral intestines of the male, a small cyst-like cavity is present in the basal region of the mucosal epithelium and filled with dozens of approximately $3 \times 5 \mu \mathrm{m}$, oval cells with a single nucleus (presumed protozoa) (Figure 4). The lumen of the intestines contains refractile digesta.

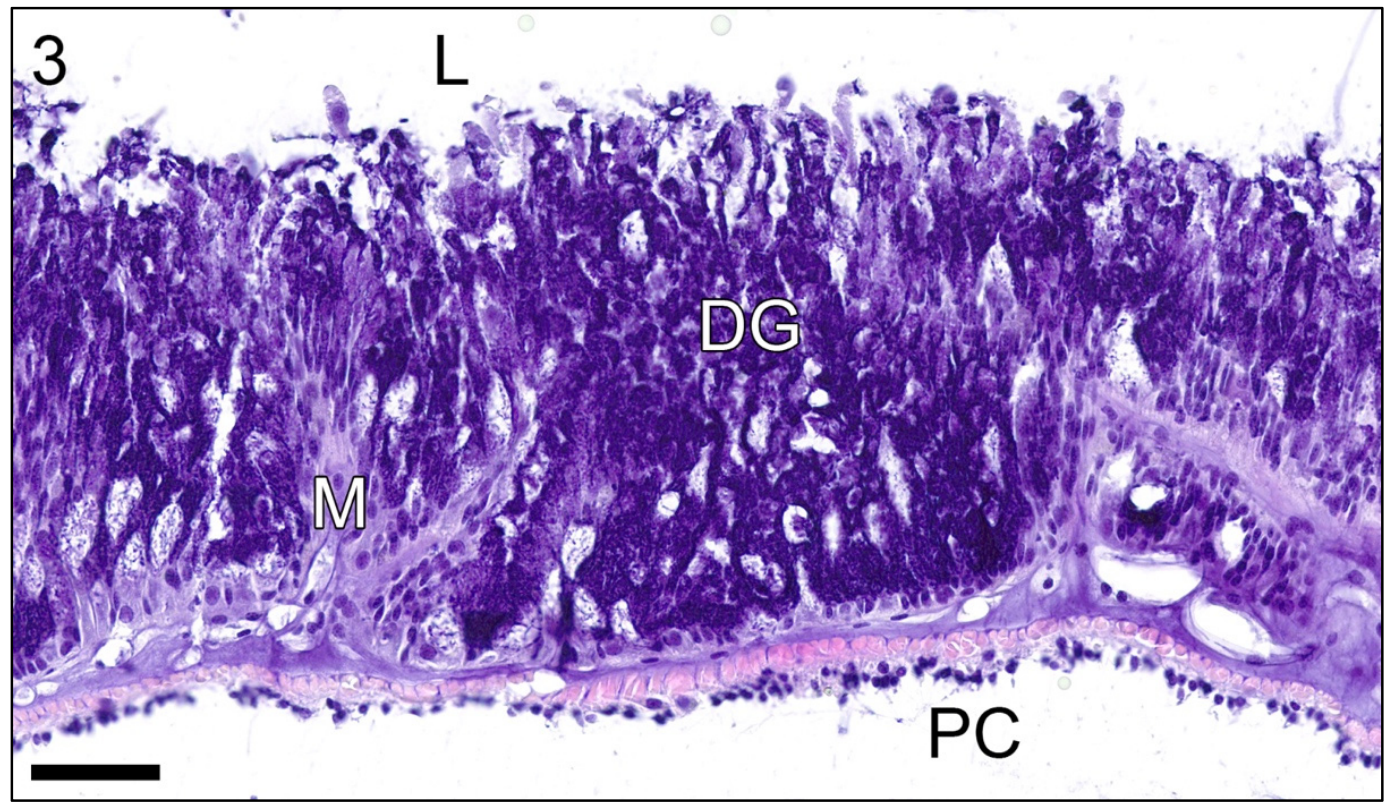

Figure 3. Histologic section of the oral mucosa of a sea pig (Scotoplanes sp.) stained with hematoxylin and eosin. DG, digestive granules; L, lumen; M, mucosa; PC, perivisceral coelom. Scale bar $=60 \mu \mathrm{m}$.

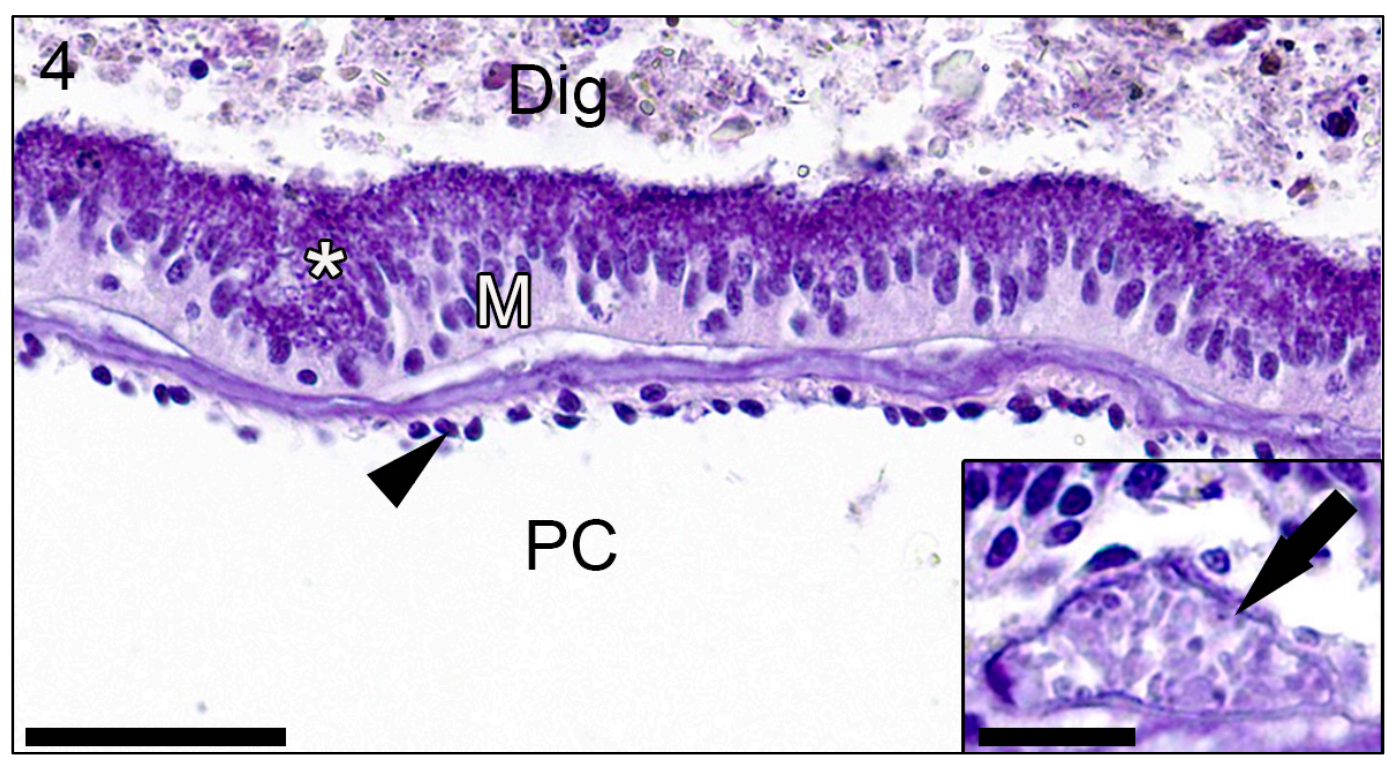

Figure 4. Histologic section of the intestines of a sea pig (Scotoplanes sp.) stained with hematoxylin and eosin. The lumen contains digesta (Dig). Arrowhead, coelomic epithelium; asterisk, digestive granules; M, mucosa; PC, perivisceral coelom. Scale bar $=60 \mu \mathrm{m}$. Inset: A cyst-like cavity (arrow) in the basilar aspect of the mucosa resembles a protozoal cyst. Scale bar $=15 \mu \mathrm{m}$.

Throughout the dermis and coelom, there are frequent cross-sections of water vascular canals that terminate in the tube feet. The entire water vascular system has an internal lining 
of cuboidal ciliated myoepithelium (called endothelium in some texts) [21,22]. The myoepithelial layer is thicker in the appendages than in the internal canals (cf. Figures 2a and 5). External to the myoepithelium is a connective tissue layer bound externally by coelomic epithelium in water vascular canals, and bound by dermis and epidermis in the tube feet [22]. The water vascular system contains clear space, coelomocytes, and some environmental debris (Figure 5). Hemal vessels consist of a thin wall of connective tissue lined externally by coelomic epithelium. Unlike the water vascular system, there is no internal lining to the hemal system. There is occasionally a small amount of muscle in the wall of the hemal vessels.

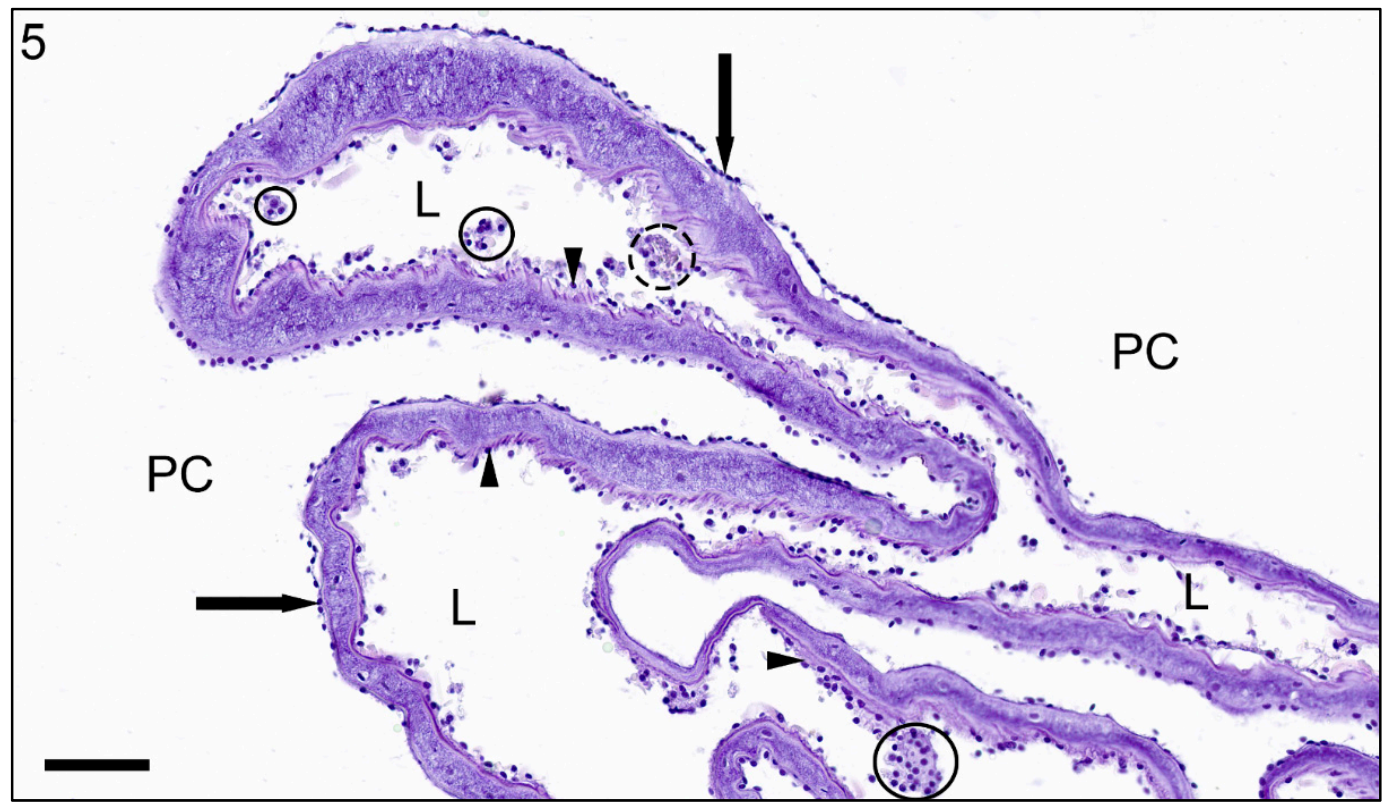

Figure 5. Histologic section of a water vascular canal of a sea pig (Scotoplanes sp.) stained with hematoxylin and eosin. The lumen (L) contains coelomocytes (solid circles), which are somteimes mixed with environmental debris (dashed circle). Coelomic epithelium (arrows) is occasionally artifactually detached from the canal wall. Arrowheads, myoepithelium; C, coelom; L, lumen. Scale bar $=60 \mu \mathrm{m}$.

Similar to other echinoderms, the nervous system consists of a network of nerves without ganglia. There is a circumoral nerve ring at the base of the buccal tentacles, and multiple branchial radial nerves that extend along the body length. Cross sections of the circumoral nerve ring are evident in cross sections of the anterior body. The nerves have peripheral cell bodies and central neuropil/axons (Figure 6).

A single gonad is present in each animal: an ovary in the female and testis in the male. The gonad consists of a thin sac of connective tissue lined externally by coelomic epithelium and lined internally by germinal epithelium. Germ cells mature centrally into previtellogenic then vitellogenic oocytes in the ovary (Figure 7). In the testis, the germ cells start as spermatogonia and mature centrally, decreasing in size to spermatocytes and finally spermatids, which are approximately $5-10 \mu \mathrm{m}$, spherical, and deeply basophilic (Figure 8) [23]. 


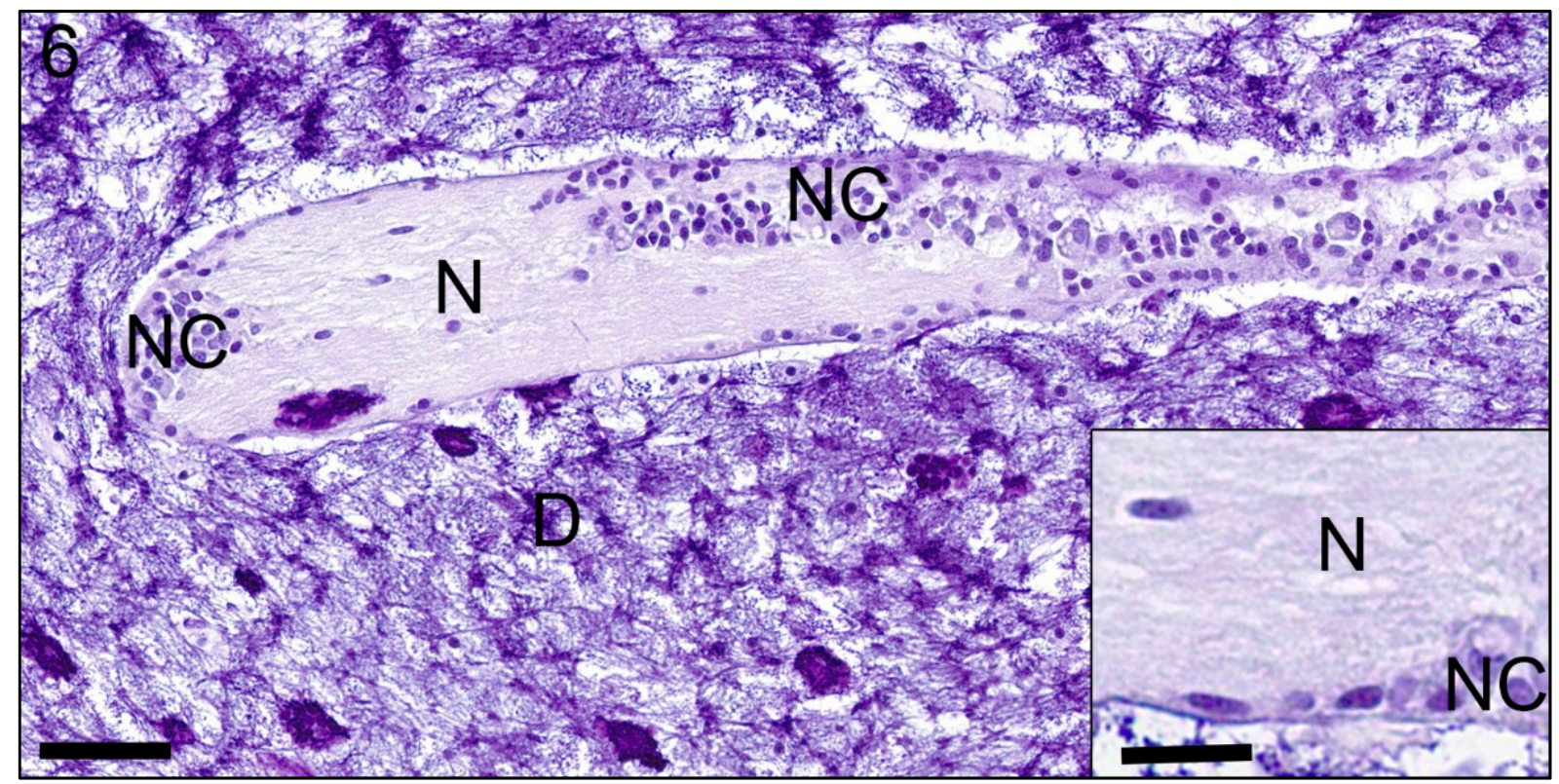

Figure 6. Histologic section of a nerve of a sea pig (Scotoplanes sp.) stained with hematoxylin and eosin. D, dermis; N, neuropil; NC, nerve cells. Scale bar $=60 \mu \mathrm{m}$. Inset: Scale bar $=30 \mu \mathrm{m}$.

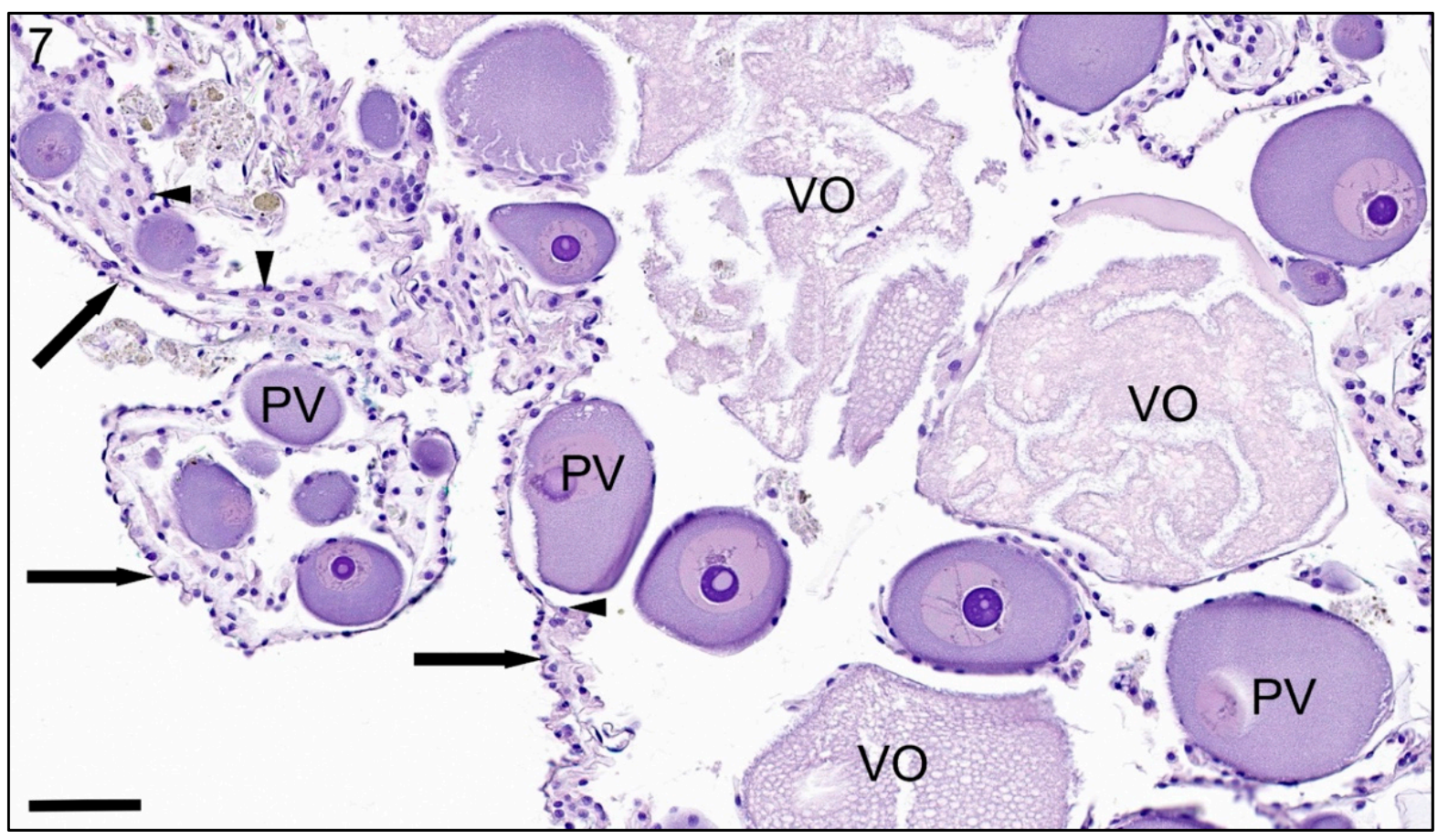

Figure 7. Histologic section of an ovary of a sea pig (Scotoplanes sp.) stained with hematoxylin and eosin. Vitellogenic oocytes (VO) have some artifactual loss of internal contents, creating artifactual, clear clefts. Arrows, coelomic epithelium; arrowheads, germinal epithelium; PV, previtellogenic oocyte. Scale bar $=60 \mu \mathrm{m}$. 


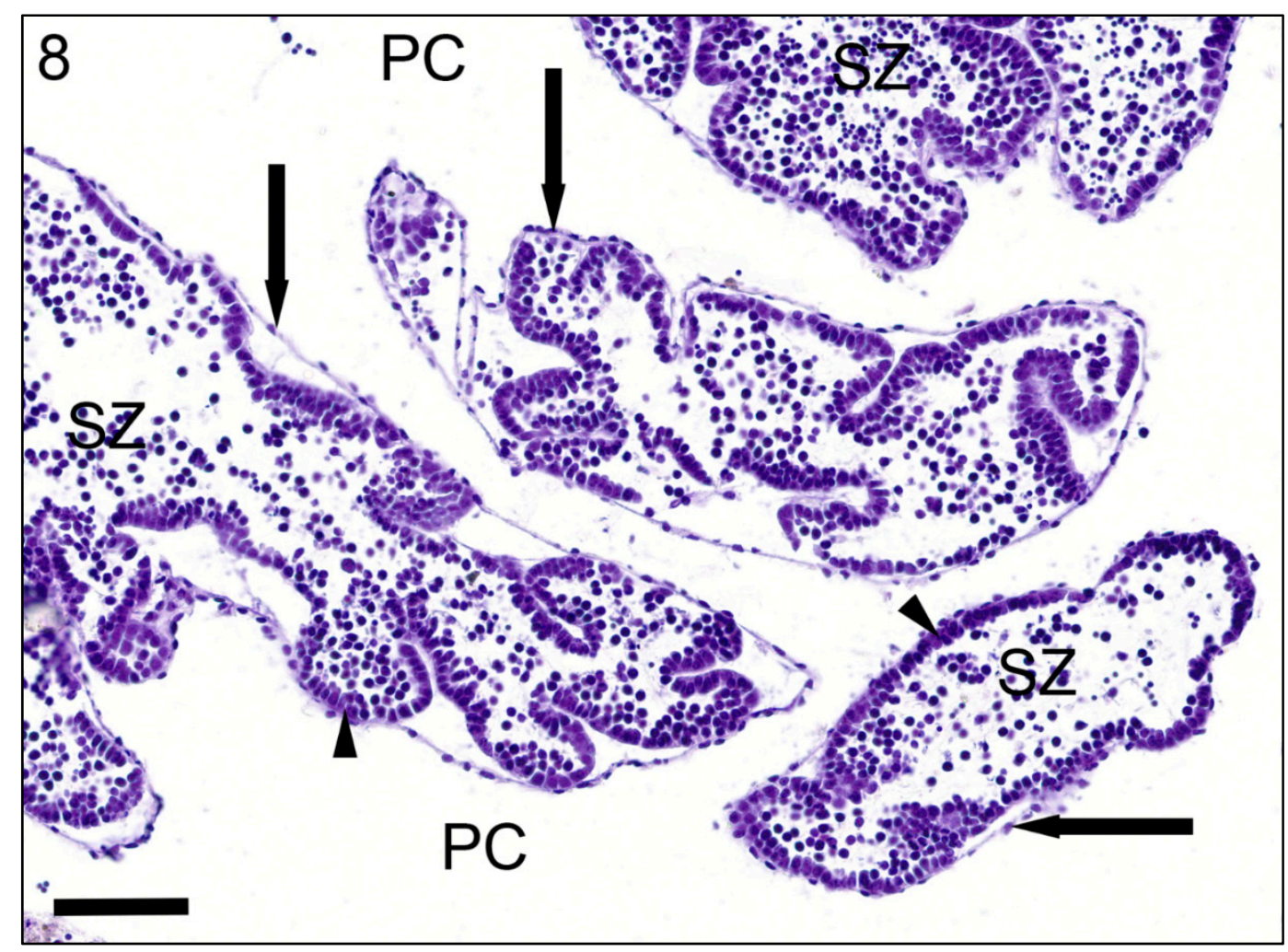

Figure 8. Histologic section of a testis of a sea pig (Scotoplanes sp.) stained with hematoxylin and eosin. Arrows, coelomic epithelium; arrowheads, spermatogonia; PC, perivisceral coelom; SZ, spematozoa. Scale bar $=60 \mu \mathrm{m}$.

\section{Discussion}

The results support the hypothesis that histologic findings of these deep-sea dwelling sea pigs are similar to other holothuroids, though there are few notable differences. Similarities and differences between Scotoplanes sp. and other holothuroids are detailed below. Ambulacral grooves are present along the polar axis of holothuroids. Depending on the species, tube feet may be concentrated in these grooves, distributed throughout the body, or be lacking altogether $[2,22]$. This species had markedly enlarged, bilaterally symmetrical tube feet, which are used for walking on the deep-sea ocean floor [24]. Depending on the holothurian species, the mouth may be surrounded by buccal tentacles, which are specialized tube feet that may be retracted by during periods of inanition [25]. Ten buccal tentacles were present in Scotoplanes sp. and had similar histologic composition to the tube feet except that the epidermis was highly folded.

In holothurians, the intestines terminate in a cuticle-lined canal that leads to the anus. This canal is the rectum in holothuroids that lack a respiratory tree, and cloaca in holothuroids that have a respiratory tree, which empties ventilator flow into the cloaca. In this Scotoplanes sp., a respiratory tree was not identified, which is consistent with gross anatomical reports of other Elasipodida [2]. The large tube feet of sea pigs are likely particularly important in gas exchange, which occurs through the body wall in holothuroids that lack a respiratory tree. Protozoal parasites, specifically coccidians, have been reported in some wild deep-sea elasipodids, particularly around the posterior digestive tract [24,26-28]. Structures resembling protozoa (i.e., small, elongate, uniform structures in a cyst-like cavity) were observed in the male Scotoplanes sp., and may represent the previously reported coccidians.

The water vascular system of holothuians is similar to other echinoderms, except the madreporite opens in the perivisceral coelom instead of in the external body wall [2,22]. The hemal and water vascular systems of this species generally appeared similar to holothuroid reports elsewhere [2,22]. Rete mirabile have been reported in some holothuroids, but were 
not identified in these animals, likely due to lack of a respiratory tree, with which the rete mirabile are anatomically associated [2].

Most holothurians are sexually dioecious with sexes in separate individuals. Unlike other echinoderms, holothuroids possess only a single gonad $[2,15,23]$. Both of these characteristics (i.e., dioecious with a single gonad) were confirmed in this Scotoplanes sp. Previous research suggests that in elasipodids, the testes of adult males are often inactive (lack gametogenesis), but ovaries of adult females consistently have active gametogenesis [26]. Both Scotoplanes sp. animals had active gametogenesis, and it is possible that this animal differs in its reproductive strategy than other elasipodids.

This study presents histologic findings in a sea pig, Scotoplanes sp. Microscopic studies of these and other animals in this class are limited. The information presented here may serve as controls for future studies, and provide useful information for deep-sea and holothurian taxonomists.

Author Contributions: Conceptualization, E.E.B.L., K.L.S. and M.M.; methodology, E.E.B.L., L.A.K., C.B., A.B., M.O., K.L.S. and M.M; formal analysis, E.E.B.L. and K.L.S.; investigation, E.E.B.L., L.A.K., C.B., A.B., M.O., K.L.S. and M.M.; resources, L.A.K. and M.M.; data curation, E.E.B.L., L.A.K., C.B., A.B., M.O., K.L.S. and M.M.; writing—original draft preparation, E.E.B.L., L.A.K., K.L.S. and M.M.; writing-review and editing, E.E.B.L., L.A.K., C.B., A.B., M.O., K.L.S. and M.M.; supervision, E.E.B.L. and M.M. All authors have read and agreed to the published version of the manuscript.

Funding: Collection of specimens was funded by the David and Lucile Packard Foundation via the Monterey Bay Aquarium Research Institute (901200).

Institutional Review Board Statement: The study was conducted according to the guidelines of the Joint Pathology Center, and approved by the Publication Approval Organization of Walter Reed National Military Medical Center (approval number 6217).

Informed Consent Statement: Not applicable.

Data Availability Statement: Not applicable.

Acknowledgments: Thank you also to the JPC technical and administrative support staff, including Ann Brown, Andrea Cherilus, Kenenya Gathers, Steven Mcnair, and Warren McNeil.

Conflicts of Interest: The authors declare no conflict of interest. The identification of specific products or scientific instrumentation does not constitute endorsement or implied endorsement on the part of the author, DoD, or any component agency. The views expressed in this manuscript are those of the author and do not reflect the official policy of the Department of Army/Navy/Air Force, Department of Defense, or U.S. Government.

\section{References}

1. Smirnov, A.V. Sea cucumbers symmetry (Echinodermata: Holothuroidea). Paleontol. J. 2014, 48, 1215-1236. [CrossRef]

2. Ruppert, E.E.; Fox, R.S.; Barnes, R.D. Echinodermata. In Invertebrate Zoology, 7th ed.; Ruppert, E.E., Fox, R.S., Barnes, R.D., Eds.; Brooks/Cole: Pacific Grove, CA, USA, 2004; pp. 872-929.

3. Théel, H. Report on Holothurioidea. Pt. I. Report of the Scientific Results of the Voyage of H.M.S. Challenger. Zoology 1882, 4, 1-176.

4. Ramirez-Llodra, E.; Brandt, A.; Danovaro, R.; De Mol, B.; Escobar, E.; German, C.R.; Levin, L.A.; Martinez Arbizu, P.; Menot, L.; Buhl-Mortensen, P.; et al. Deep diverse and definitely different: Unique attributes of the world's largest ecosystem. Biogeosciences 2010, 7, 2851-2899. [CrossRef]

5. Woolley, S.N.; Tittensor, D.P.; Dunstan, P.K.; Guillera-Arroita, G.; Lahoz-Monfort, J.J.; Wintle, B.A. Deep-sea diversity patterns are shaped by energy availability. Nature 2016, 533, 393-396. [CrossRef] [PubMed]

6. Roberts, D.; Gebruk, A.; Levin, V.; Manship, B.A.D. Feeding and digestive strategies in deposit-feeding holothurians. In Oceanography and Marine Biology; Barnes, M., Gibson, R.N., Eds.; Taylor and Francis: Oxford, UK, 2000; pp. $257-310$.

7. Barry, J.P.; Taylor, J.R.; Kuhnz, L.A.; De Vogelaere, A.P. Symbiosis between the holothurian Scotoplanes sp. and the lithodid crab Neolithodes diomedeae on a featureless bathyal sediment plain. Mar. Ecol. 2016, 38, 1-10.

8. Jacobsen Stout, N.; Kuhnz, L.; Lundsten, B.; Schlining, K.; Schlining, B.; Von Thun, S. The Deep-Sea Guide (DSG); Monterey Bay Aquarium Research Institute: Monterey, CY, USA, 2021.

9. Diaz-Balzac, C.A.; Abrea-Arbelo, J.E.; Garcia-Arraras, J.E. Neuroanatomy of the tube feet and tentacles in Holothuria glaberrima (Holothuroidea, Echinodermata). Zoomorphology 2010, 129, 33-43. [CrossRef] 
10. Ehlers, U. Ultrastructue of the statocysts in the apodus sea cucumber Leptosynapta inhaerens. (Holothuroidea, Echinodermata). Acta Zool. 1997, 78, 61-68. [CrossRef]

11. Ezhova, O.V.; Ershova, N.A.; Malakhov, V.V. Microscopic anatomy of the axial complex and associated structures in the sea cucumber Chiridota laevis Frabricius, 1780 (Echinodermata, Holothuroidea). Zoomorphology 2017, 136, 205-217. [CrossRef]

12. Frick, J.E.; Ruppert, E.E.; Wourms, J.P. Morphology of the ovotestis of Synaptula hydriformis (Holothuroidea, Apoda): An evolutionary model of oogenesis and the origin of egg polarity in echinoderms. Invertebr. Biol. 1996, 115, 46-66. [CrossRef]

13. Foster, G.G.; Hodgson, A.N. Feeding, tentacle and gut morphology in five species of southern African intertidal holothuroids (Echinodermata). S. Afr. J. Zool. 1996, 31, 70-79. [CrossRef]

14. Kamenev, Y.O.; Dolmatov, I.Y.; Frolova, L.T.; Khang, N.A. The morphology of the digestive tract and respiratory organs of the holothurian Cladolabes schmeltzii (Holothuroidea, Dendrochirotida). Tissue Cell 2013, 45, 126-139. [CrossRef] [PubMed]

15. Kremenetskaia, A.; Ezhova, O.; Drozdov, A.L.; Rybakova, E.; Gebruk, A. On the reproduction of two deep-sea Arctic holothurians, Elpidia heckeri and Kolga hyaline (Holothuroidea: Elpidiidae). Invertebr. Reprod. Dev. 2020, 64, 33-47. [CrossRef]

16. Mashanov, V.S.; Zueva, O.R.; Heinzeller, T.; Dolmatov, I.Y. Ultrastructure of the circumoral nerve ring and the radial nerve cords in holothurians (Echinodermata). Zoomorphology 2006, 125, 27-38. [CrossRef]

17. Mashanov, V.S.; Frolova, L.T.; Dolmatov, I.Y. Structure of the digestive tube in the Holothurian Eupentacta fraudatrix (Holothuroidea: Dendrochirota). Russ. J. Mar. Biol. 2004, 30, 314-322. [CrossRef]

18. Utzeri, V.J.; Ribani, A.; Bovo, S.; Taurisano, V.; Calassanzio, M.; Baldo, D.; Fontanesi, L. Microscopic ossicle analyses and the complete mitochondrial genome sequence of Holothuria (Roweothuria) polii (Echinodermata; Holothuroidea) provide new information to support the phylogenetic positioning of this sea cucumber species. Mar. Genom. 2020, 51, 100735. [CrossRef] [PubMed]

19. Smiley, S. Holothuroidea. In Microscopic Anatomy of Invertebrates; Harrison, F.W., Chia, F., Eds.; Wiley-Liss: Hoboken, NJ, USA, 1994; Volume 14, pp. 401-471.

20. Hedgpeth, J.W. Galathea Report. Scientific results of the Danish deep-sea expedition round the world 1950-52. Science 1960, 131, 1521. [CrossRef]

21. Roberts, D.; Moore, H.M. Tentacular diversity in deep-sea deposit-feeding holothurians: Implications for biodiversity in the deep sea. Biodivers. Conserv. 1997, 6, 1487-1505. [CrossRef]

22. Newton, A.L.; Dennis, M.M. Echinodermata. In Invertebrate Histology; LaDouceur, E.E.B., Ed.; Wiley: Hoboken, NJ, USA, 2021; pp. 1-18.

23. Galley, E.A.; Tyler, P.A.; Smith, C.R.; Clarke, A. Reproductive biology of two species of holothurian from the deep-sea order Elasipoda, on the Antarctic continental shelf. Deep Sea Res. II 2008, 55, 2515-2526. [CrossRef]

24. Hansen, B. Photographic Evidence of a unique type of walking in deep-sea Holothurians. Deep Sea Res. Oceanogr. Abstr. 1972, 19, 461-462. [CrossRef]

25. Feral, J.P.; Massin, C. Digestive systems: Holothuroidea. In Echinoderm Nutrition; Jangoux, M., Lawrence, J.M., Eds.; CRC Press: Boca Raton, FL, USA, 1982; pp. 191-212.

26. Billett, D.S.M. The Ecology of Deep Sea Holothurians. Ph.D. Thesis, University of Southhampton, Southampton, UK, 1988.

27. Massin, C.; Jangoux, M.; Sibuet, M. Description d' Ixoreis psychropotae nov. gen., nov. sp., coccidie parasite du tube digetif de I'Holothurie abyssal Psychropotes longicauda Theel. Protistologica 1978, 14, 253-259.

28. Massin, C. Structures digestives d'holothuries Elasipoda (Echinodermata): Benthogone rosea Koehler, 1896 et Oneirophanta mutabilis Theel, 1879. Arch. Biol. 1984, 95, 153-185. 